\title{
Eco-innovation as a tool to support sustainable development and increase the competitiveness of enterprises
}

\author{
Pavol Kral ${ }^{1 *}$, Katarina Janoskova ${ }^{2}$ \\ ${ }^{1}$ University of Zilina, Faculty of Operation and Economics of Transport and Communication, \\ Department of Economics, Univerzitna 8215/1, 01016 Zilina, Slovak Republic \\ ${ }^{2}$ University of Zilina, Faculty of Operation and Economics of Transport and Communication, \\ Department of Economics, Univerzitna 8215/1, 01016 Zilina, Slovak Republic
}

\begin{abstract}
Research background: For several years, the world's leading producers have been looking for new possibilities for an environmentally sustainable production model that will make it possible to generate ecological products. Eco-innovation is a tool for increasing the competitiveness of producers, reducing their costs and providing new solutions for customers whose environmental awareness is constantly growing.

Purpose of the article: The purpose of the paper is to point out the key characteristics eco-innovations measurement and to define basic attributes that allow answering strategic questions for the future application of ecoinnovations in business practice, identify new possibilities of applying ecoinnovations and finding suitable support formats. These attributes will be defined on the basis of knowledge of the theoretical background of the issue of eco-innovation, analysis of strategic documents at the EU level and evaluation of successful projects.

Methods: An analysis of the available scientific literature including electronic sources with a subsequent synthesis of the acquired knowledge, will be applied for the factual theoretical definition of solved problem. Descriptive statistics indicators will assess the current situation and development of the eco-innovation segment at EU member state level.

Findings \& Value added: The results will enable business practice to understand the essence of eco-innovation, get to know this environment and the current trend, as well as to create a suitable platform for planning successful eco-innovation projects.
\end{abstract}

Keywords: Eco-innovation, measuring eco-innovation, sustainable development, enterprise competitiveness

JEL Classification: 030, 031

\footnotetext{
${ }^{*}$ Corresponding author: pavol.kral@ffpedas.uniza.sk
} 


\section{Introduction}

Eco-innovation is a concept that is can be different define. For example Rennings (2000) ecoinnovation defined as "all efforts from relevant actors that introduce, develop, and apply new ideas, behaviours, products and processes and contribute to reducing environmental burdens or ecologically specified sustainability targets“. Fussler and James (1996) define ecoinnovation as "new products and processes which provide customer and business value but significantly decrease environmental impacts". Eco-innovation is the production, assimilation, or exploitation of a product, production process, service, or management or business method that is novel to the organization (developing or adopting it), and that results, throughout its life cycle, in a reduction of environmental risk, pollution, and other negative impacts of resource use compared with relevant alternatives (Kemp and Pearson, 2007). Lešková (2009), claims that eco-innovation decreases material demands by using closed material flows or by creating or using new materials. At the same time, ecological innovations are focused on decreasing energy demands or creating/using alternative sources of energy. They also decrease the total amount of emissions or existing environmental load and health risks while supporting healthy lifestyles and sustainable consumption. According Loucanova et al. (2015) eco-innovations in its essence represent the choice of suitable materials, processes and distribution methods that are used with lower consumption of energy, lower consumption of natural resources, and overall, with lower environmental load.

\section{Methods}

Measuring country performance of eco-innovation has started via indices or scoreboards, which come with indicators and scores and help come up with benchmarks across countries. Policy and innovation actors can thus learn about diagnosing different areas of ecoinnovation, monitoring trends and directions, and drawing lessons about the strengths and weaknesses across countries. Therefore, such attempts go beyond measuring and facilitate communication on eco-innovation for public and private actors alike. (Park et al., 2017)

Measuring eco-innovation enables us to assess the progress of the components of ecoinnovation. In practice, it helps policy makers to understand the overall trend of ecoinnovation and its drivers and barriers, and to design effective policies and framework conditions for eco-innovation (Arundel, 2009).

Carrillo et al. (2010) identify three different approaches the role and impacts of ecoinnovations are proposed:

1. Component addition: development of additional components to minimize and repair negative impacts without necessarily changing the process and system that generate those impacts, as with "end-of-pipe" technologies.

2. Sub-system change refers to eco-efficient solutions and the optimisation of subsystems, leading to the improvement of the sub-system and a reduction of its negative environmental impacts.

3. System change involves the redesign of systems towards eco-effective solutions, reducing the environmental impacts on the ecosystem and society at large. Moving towards system change challenges companies and society to redefine their production and behavioural patterns.

Eco-innovation can be measured directly or indirectly. Kemp and Pearson (2007) classified measurements into four types to quantify technological changes, considering the process of eco-innovation:

1. input measures - research and development (R\&D) expenditures, R\&D personnel and innovation expenditures.

2. intermediate output measures - patents, scientific publication and citations 
3. direct output measures - data on new product sales, based on product and trade information databases.

4. indirect impact measures - company information about innovation and ecoinnovation performance, obtained from the specially designed surveys

Many scholars pointed out the key characteristics of indicators (Table 1).

Table 1. Characteristics of indicators

\begin{tabular}{|c|c|c|c|}
\hline Author & Hollander (2002) & Phillips (2003) & Hammond (1995) \\
\hline Criteria & $\begin{array}{ll}\text { - } & \text { validity } \\
\text { - } & \text { relevance } \\
\text { - } & \text { consistency and } \\
& \text { reliability } \\
\text { - } & \text { measurability } \\
\text { - } & \text { clarity } \\
\text { - } & \text { comprehensiveness } \\
\text { - } & \text { cost-effectiveness } \\
\text { - } & \text { comparability } \\
\text { - } & \text { attractiveness to the } \\
& \text { media. }\end{array}$ & $\begin{array}{l}\text { - be appropriate to its political, } \\
\text { institutional, jurisdictional, or } \\
\text { other context } \\
\text { - be meaningful and useful to } \\
\text { stakeholders } \\
\text { - use affordable, relevant, and } \\
\text { accessible data sources } \\
\text { - clearly state and accurately } \\
\text { reflect its intent } \\
\text { - result from close } \\
\text { collaborations with } \\
\text { stakeholders during the } \\
\text { selection, application and } \\
\text { review process } \\
\text { - connect and be consistent } \\
\text { with well-articulated vision } \\
\text { statements and goals } \\
\text { - cause a government to take } \\
\text { action }\end{array}$ & $\begin{array}{l}\text { - useful to their intended } \\
\text { audience } \\
\text { - pertinent to policy } \\
\text { concerns } \\
\text { - highly aggregated }\end{array}$ \\
\hline
\end{tabular}

Source: author (2021)

Published research (Arundel and Kemp, 2009) measured eco-innovation using the following four measures:

1. input - research and development (R\&D) expenditures.

2. inter-mediate output - number of patents and the number and types of scientific publications

3. direct output - number of innovations, descriptions of individual innovations, and data on sales of new products,

4. indirect impact - derived from aggregate data, such as changes in resource efficiency and productivity.

According Rozkrut (2014) eco-innovation indicators are:

A. Environmental Benefits During The Production

1. Reduced material use per unit of output

2. Reduced energy use per unit of output

3. Reduced $\mathrm{CO} 2$ footprint

4. Replaced materials with less polluting or hazardous substitutes

5. Reduced air, water, soil or noise pollution

6 . Recycled waste, water or materials

B. Environmental Benefits After Sales

1. Reduced energy use

2. Reduced air, water, soil or noise pollution

3. Recycled waste, water or materials

C. Motivation

1. Existing environmental regulations or taxes on pollution 
2. Environmental regulations or taxes expected in the future

3. Government grants, subsidies or other financial incentives

4. Current or expected market demand from customers

5 . Voluntary codes, agreements for good practice.

The performance of EU Member States on environmental innovations is measured by the summary Eco-innovation index. It was developed in 2010 as a tool to assess and illustrate eco-innovation performance across the EU member states. This index is based on five basic thematic areas:

1. Eco-innovation inputs - financial and human capital investment in eco-innovative.

2. Eco-innovation activities - extent to which companies in a given country are active in eco-innovation.

3. Eco-innovation outputs - number of patents, academic literature and media coverage.

4. Resource efficiency outcomes - efficiency of resources and GHG emission intensity.

5. Socio-economic outcomes-measure the positive societal as well as economic outcomes of eco-innovation.

The structure of the index consists composite indicator obtained by taking an unweighted average of the 16 indicators included in the measurement framework:

1. Governments environmental and energy R\&D appropriations and outlays (\% of GDP)

2. Total R\&D personnel and researchers (\% of total employment)

3. Total value of green early stage investments (USD/capita)

4. Implementation of resource efficiency actions among SMEs (Score)

5. Implementation of sustainable products among SMEs (\% of surveyed firms)

6. Number of ISO 14001 certificates (per mln population)

7. Eco-innovation related patents (per mln population)

8. Eco-innovation related academic publications (per mln population)

9. Eco-innovation related media coverage (per mln population)

10. Exports of products from eco-industries (\% of total exports)

11. Employment in environmental protection and resource management activities (\% of workforce)

12. Value added in environmental protection and resource management activities ( $\%$ of GDP)

13. Material productivity (GDP/Domestic Material Consumption)

14. Water productivity (GDP/total fresh water abstraction)

15. Energy productivity (GDP/gross inland energy consumption)

16. GHG emissions intensity (CO2e/GDP)

Every areas is presented by an index. The eco-innovation index is counted individually for each country, where there are specific figures of a single indicator weighted with the share of population, so the EU average is calculated. Summing up of the underlying data is used for direct calculation of the EU average of indicators that are displayed in absolute numbers. In order to exclude statistical outliers, the $5 \%$ and the $95 \%$ Quantile are introduced as thresholds. Values above or below the thresholds are replaced by the adequate threshold value. The thresholds correct the data that is used for the calculation of the EU average. To normalize different indicators a "Distance-to-reference" method is used, the EU average is defined as the reference and a set is defined as a value of 100 . Countries whose figures are higher than the EU average obtain a higher score than 100 and countries whose figures are lower achieve less. The specific value is dependent on the deviation from the EU average. Missing data is not replaced by estimations; when the data of a country is not available, this country does not receive a result for the respective indicator. When calculating the index of 
the five areas, unweighted mean of the underlying indicators is used. Also, calculation of the overall scoreboard of a Member State of the EU uses the unweighted mean of the 16 subindicators. (Loucanova et al., 2015)

Another index is ASEM Eco-Innovation Index has been developed in 2012 by ASEIC, (ASEM SMEs Eco-Innovation Center) which has annually assessed eco-innovation phenomena across ASEM member countries (31 countriesfrom Europe and 20 countries from Asia). It is composed of 20 indicators divided into four components:

1.Eco-innovation Capacity (five indicators)

1.1. Nation's Economic Competitiveness

1.2. Nation's General Innovation Capacity

1.3. Green Technology R\&D Institution Capacity

1.4. Green Technology possessed/acquired Enterprises

1.5. Awareness of Sustainability Management

2. Eco-innovation Supporting Environment (four indicators)

2.1. Government's R\&D expenditure in Green Industry

2.2. Implementation of Environmental Regulations

2.3. Maturity of Investment Setting for Green Technology Industry

2.4. Investment Scale of Green Technology SMEs

3. Eco-innovation Activity (five indicators)

3.1. Commercialization Level of Green Technology

3.2. Enterprises' Participation on Environmental Management System

3.3. Economic Influence of Leading Environmentally Responsive Enterprises

3.4. Green Patents

3.5. Activeness of Renewable Energy Utilization

4. Eco-innovation Performance (six indicators)

4.1. Level of Environmental Impact on Society

4.2. $\mathrm{CO} 2$ Emission Intensity

4.3. Nation's Energy sustainability level

4.4. Water Consumption Intensity

4.5. Jobs in Green Technology Industry

4.6. Green Industry Market Size

\section{Results and disscussion}

Eco-innovation can serve as a tool by which enterprises attempt to transform environmental restrictions into opportunities to ensuring economy, reduce costs, to obtain a better reputation, and to take gaining a competitive advantage.

Ryszko (2016) reported that companies can, through technological eco-innovation, not only improve their corporate image and achieve better customer satisfaction, but can also generate an increase in market share, profit growth, return on sales, etc. Because technological eco-innovation reduces environmental impact and improves business performance, it simultaneously contributes to environmental and economic pillars of sustainable development.

Slovakia in 2021, considering the appraisal of the performance in the area of ecoinnovation, belongs to the group of economies whose eco-innovation index does not reach high level (figure 1). Positive is that eco-innovations in Slovakia have a rising tendency, from the perspective of the development during the last years. 


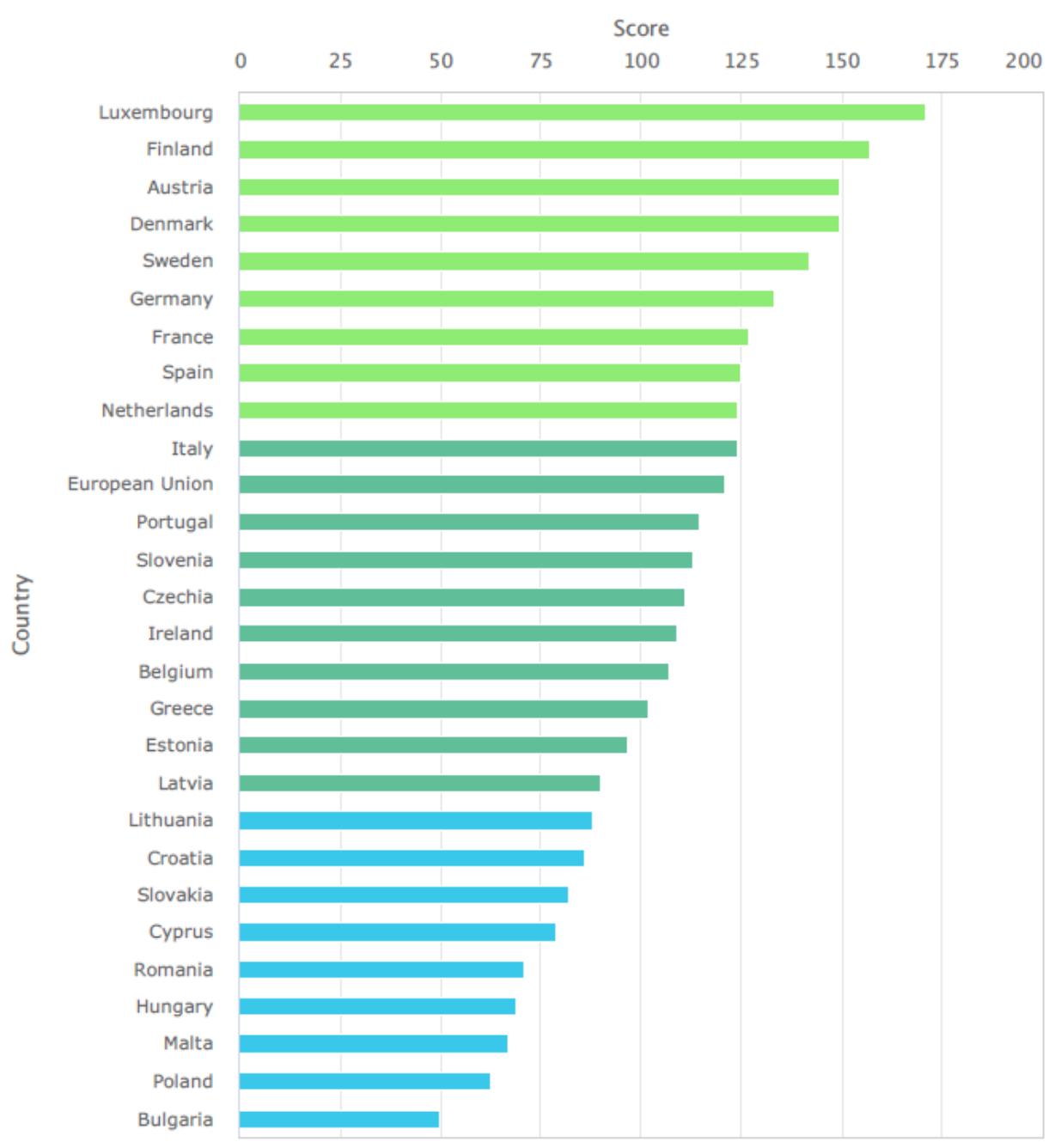

\section{Performance groups}

Eco-I Leader

Figure 1. Eco-Innovation Index (2021)

Source: https://ec.europa.eu/environment/ecoap/indicators/index_en (2021)

Favourable development of eco-innovative performance in Slovakia is influenced mainly by the activities performed by the companies that are implementing innovative activities for reduction of material inputs per unit of output, activities for reduction of energy inputs per unit of output and environmental management. However, there is still space for an improvement, as Overall Eco-innovation Scoreboard of Slovakia is below average within the standards of the EU. For achieving the improvement of this situation it is convenient to focus mainly on the support of exports of products from eco-industries, employment in ecoindustries, research and development in the area of environment, energy research within the open system of innovations and also research in other areas connected to the environmental policy of Slovakia. (Loucanova et al., 2015) 
Results of scientific work Triguero et al. (2013) show that those entrepreneurs who give importance to collaboration with research institutes, agencies and universities, and to the increase of market demand for green products are more active in all types of eco-innovations. Also shows that market share only has a significant positive influence on eco-product and ecoorganizational innovations, while cost-savings are solely significant for eco-process innovations. Supply-side factors seem to be a more important driver for environmental processes and organizational innovations than for environmental product innovations. Companies who value increasing or stable market share as very important drivers of innovation report a higher probability of adopting product eco-innovations. Environmental product innovation is mainly related to the strategic market behaviour of firms and the search for competitiveness. The demand side is also relevant because firms valuing very much the market demand for green products are shown to develop more environmental product innovations. The firmsize has a positive effect on environmental activities in general. The large companies positively related with the decision to eco-innovate (size is showed as a proxy for potential barriers for eco-innovation). Small companies face more difficulties to apply eco-innovations.

\section{Conclusion}

Eco-innovation generally positively influences the environmental, economic, and social growth of companies that gradually adopt sustainable development. Therefore, it is convenient to analyze the critical issues, which may also influence the desired positive development of eco-innovation in the future (Loucanova and Nosalova, 2020).

Eco-innovations because of an increased interest from the side of consumers and society are becoming key innovations for companies and important tool of competitiveness. Companies in developed countries are increasingly aware on the potential benefits from improved environmental.

It is necessary to look at the planned eco-innovation in terms of economic efficiency (Zauskova et al., 2015). When implementing environmentally friendly products, companies use marketing tools that are well established and proven for other products. It is important to build the trust of customers that these products deliver measurable benefits to the environment and are equally well-suited and cost-effective as the previously used product that was not environmentally significant and beneficial (Krizanova et al., 2013).

Companies should see the eco-innovation concept as a sustainable way to increase their potentialcompetitiveness taken into account the growing environmentally consciousness of current European consumers.

\section{Acknowledgement}

The contribution is an output of the project VEGA 1/0619/20 Fundamental research of quantitative and qualitative determinants of enterprise innovation potential and innovation performance in relation to increasing its competitiveness.

\section{References}

1. Arundel A., \& Kemp R. (2009). Measuring eco-innovation. UNI-MERIT Research Memorandum, 2009-017.

2. Arundel, A., \& Kemp, R. (2009). Measuring Eco-Innovation. UNU-MERIT: Maastricht, The Netherlands. 
3. Carrillo-Hermosilla, J., del Rio, P., \& Konnola, T. (2010). Diversity of eco-innovations: reflections from selected case studies. Journal of Cleaner Production 18(10-11), 10731083.

4. Fussler, C., \& James, P. (1996). Driving eco-innovation: a breakthrough discipline for innovationand sustainability (Pitman Ltd., London, 1996).

5. Hammond, A. (1995). Environmental Indicators: A Systematic Approach to Measuring and Reporting on Environmental Policy Performance in the Context of Sustainable Development. World Resource Institute: New York, NY, USA.

6. Hollander, J. (2002). Measuring Community: Using Sustainability Indicators in Devens, Massachusetts. Plan. Casebook, 39, 1-7.

7. Kemp, R., \& Pearson, P. (2007). Final Report MEI Project About Measuring EcoInnovation (Call FPG-2005-SSP-5A), European Commission, Brussels, Belgium.

8. Kemp, R., \& Pearson, P. (2007). Final Report MEI Project about Measuring EcoInnovation; UM Merit: Maastricht, The Netherlands.

9. Krizanová, A., Majerova, J., \& Zvarikova, K. (2013). Green Marketing as a Tool of Achieving Competitive Advantage in Automotive transport. 17th International Conference on Transport Means, Transport Means - Proceedings of the International Conference, 45-48.

10. Lešková, I. A. (2009). Politika eko-inovácií a jej prejavy v automobilovom priemysle [Eco-innovation policy in automotive industry]. Transfer Inovácii 13, 37-40.

11. Loucanova, E., \& Nosalova, M. (2020). Eco-innovation Performance in Slovakia: Assessment Based on ABC Analysis of Eco-innovation Indicators. BioResources 15(3), 5366-5365.

12. Loucanova, E., Parobek, J., Kalamarova, M., Palus, H., \& Lenoch, J. (2015). Ecoinnovation performance of Slovakia. Procedia Economics and Finance 26, 920 - 924.

13. Park, M.S., Bleischwitz, R., Han, K.J., Jang, E.K., \& Joo, J.H. (2017). Eco-Innovation Indices as Tools for Measuring Eco-Innovation. Sustainability 9(12), Article Number 2206

14. Phillips, R. (2003). Community Indicators. The American Planning Association: Chicago, IL, USA.

15. Rennings, K. (2000). Redefining innovation-Eco-innovation research and the contribution from ecological economics. Ecol. Econ. 32, 319-332.

16. Rozkrut, D. (2014). Measuring Eco-Innovation: Towards Better Policies To Support Green Growth. Folia Oeconomica Stetinensia 1, 137-148.

17. Ryszko, A. (2016). Proactive environmental strategy, technological eco-innovation and firm performance - Case of Poland. Sustainability 8(2), Article number 156.

18. Triguero, A., Moreno-Mondejar, L., \& Davia, M.A. (2013). Drivers of different types of eco-innovation in European SMEs. Ecological Economics 29, 25-33.

19. Zauskova, A., Bezakova, Z., \& Grib, L. (2015). Marketing Communication in Ecoinnovation Process. Procedia Economics and Finance, 34, 670 - 675. 